\title{
Rural Property Rights in a Peace Process: Lessons from Mozambique
}

\author{
Jon D. Unruh, McGill University
}

Land rights issues have proven to be one of the most vexing problems in a peace process. In the developing world and the Middle East, the disintegration of land and property rights institutions during armed conflict, and yet the importance of land, homeland, and territory to the cause and conduct of conflict presents particular dilemmas for recovery. Such a process must attempt to both address issues fundamental to the cause and maintenance of the conflict, as well as land related problems important to recovery.

\section{[A] Land Tenure and Civil Conflict}

The importance of land tenure (rural property rights) issues during and subsequent to civil conflict is reflected in the significant role that agrarian reform has played in many insurgent and revolutionary agendas. As Shipton (1994:347) observes, "nothing evokes deeper passions or gives rise to more bloodshed than do disagreements about territory, boundaries, or access to land resources." Managing such issues in a peace process is not only important to avoiding disenfranchisement of local populations from land rights - a primary factor contributing to conflict - but also to the secure re-engagement of populations in familiar land uses, agricultural production, food security, and trade opportunities important to recovery.

Subsequent to the end of a conflict, land tenure issues are thrust to the fore over large geographic areas in a short period of time for considerable numbers of people. And like the complex histories involving property, land, and territory that play a role in conflict scenarios, postwar re-establishment of ownership, use, and access rights for individuals, communities and peoples will likewise be complicated and problematic, providing significant potential for renewed confrontation (Unruh 2002a). Because of the spatial nature of both armed conflict and land tenure, geographers are uniquely suited to addressing the problem of land tenure during postwar recovery. Such a topic resides within the fields of political ecology (Bryant 1992) and political economy (Emel and Peet 1989; Marston 1983) within the discipline.

\section{[A] The Peace Process in Mozambique}

The recent peace process in Mozambique provides an important example. The civil war ending in the early 1990s (Sidaway 1992:239) initiated a process that needed to manage the reintegration of over six million dislocatees and refugees (approximately 40 percent of the national population) back into primarily agricultural pursuits. Land 
disputes were very frequent and acute, especially between commercial land interests operating from the formal national land tenure system, and returnees operating largely from traditional customary tenure systems. With weapons still in wide circulation and land issues becoming increasingly fraught, there was significant concern that the numerous land disputes might provide a flashpoint for a return to armed conflict. Because the national land law held documented title--which almost all returnees did not have--to be the only legitimate evidence in land disputes, there existed a very problematic disconnect between opportunities to resolve disputes peaceably, and postwar reality (Unruh 2001:4). Geographical research and subsequent work by a geographer with both the Mozambican Interministerial Land Commission and a group of international donors led to more formalized definition of traditional customary evidence (by necessity spatially referenced) useful in land dispute resolution; and the inclusion of this evidence in national land policy reform, including a new land law.

The problems were numerous. The formal land tenure system was crippled, rendering itself open to abuses and non-compliance for important steps within formal law. The postwar reduction of resources, personnel, and institutions responsible for executing and enforcing formal legal procedures, together with continued insecurity in numerous parts of the country, combined to significantly reduce the capacity and legitimacy of the formal system. At the same time the customary land tenure system underwent substantial change during the conflict, especially for those for whom dislocation and migration to new areas was a significant experience (Unruh in press).

The resulting postwar land tenure situation, especially in agronomically favorable or important areas, was one where the formal tenure system was used by commercial interests to gain access to land that was also allocated under customary tenure regimes to small-scale agriculturalists. Because these different groups appealed to different sets of evidence that resided within different, and often incompatible or opposing notions of legitimacy (often due to the war) for claim or rights to land, there were no conflict resolution institutions able to legitimately consider the different forms of evidence. [A] The Role of Spatially Explicit Evidence for Land Rights

Formal land dispute resolution employed by the state favored claimants in possession of some form of documentation as evidence for a claim. Those not participating in the state land tenure system used (and continue to use) an array of customary spatially referenced evidence that connects them to a community, and to community land, with history of occupation and physical signs of occupation playing a significant role in this connection. Customary institutions for land dispute resolution held membership in local lineages and community, and testimony from lineage and community members regarding history of land use and occupation, to be legitimate evidence. Commercial or 'outside' land interests did not have such evidence. While 
documents were admissible forms of evidence in formal Mozambican law, oral testimony and corroboration were not. Thus based on admissible forms of evidence, formal dispute resolution decisions were made in favor of documentation. Such an inequitable arrangement, operating in aggregate, carried serious risks toward instability, impoverization, land degradation, and rural exodus (Unruh 2001:6).

The problem, more generally, became one of defining what was regarded as legitimate evidence. Within the domain of adjudication, the question of who controls the 'language,' and the 'translations,' of reality into evidence for use in adjudication, mapping, and demarcations, becomes critically important (Shipton 1994:348; Murphy 1990:545). This control legitimizes or de-legitimizes spatial units of aggregation, kinds of rights, or ways of land use, or they justify appropriations and expropriations (Shipton 1994:349). Such an evidentiary problem in a postwar context becomes particularly difficult because the prevalence of weapons can quickly lead to violence in land disputes.

\section{[A] Geographical Research on the Evidence Problem}

The research on the spatio-evidence problem examined customary evidence according to their social and cultural-ecological character. Social evidence is largely oral or testimonial, and is provided or confirmed by members of a community or lineage. This type of evidence relates to historical occupation, and ties individuals, households, and land to local communities. Cultural-ecological evidence is defined as that which exists due to smallholder activity on the landscape, such as the presence of economically valuable trees, current and historical field boundaries, tombs, etc. This type of evidence best demonstrates occupation. Cultural ecological evidence however is problematic on its own, and to a significant degree needs corroborative social evidence for meaning. In this regard, testimony from neighbors, relatives, and the customary leadership regarding boundaries, land occupation, land and tree tenure, land inheritance and the history of these, will be much more valuable in a land claim if they are all linked. Social evidence ties individuals to communities, and cultural-ecological evidence corroborated by social evidence constitutes the connection between the physical signs of human occupation of land and the social aspects that play a large role in creating cultural-ecological evidence. [A] Policy Contributions

The results of the research were incorporated into the Land Commission's deliberations on land policy reform for Mozambique. On July 31, 1997, after two weeks of parliamentary debate, the National Assembly approved a new land law. The key changes regarding conflict resolution that were adopted as articles in the revised law indicate that:

- the use of nonwritten forms of customary evidence, such as oral testimony, to defend claims to land is permitted; 
- rural smallholders are explicitly granted land use rights through "occupation," and such rights are not to be prejudiced by or inferior to rights received through a formal written title;

- local community "participation" is required in the formal titling process; and,

- the registering of land in the name of the local community is permitted (Unruh 2002b).

Efforts are underway in Mozambique to encourage domestic and international nongovernmental organizations to play a role in bringing about local understanding of the revised land law. Ultimately the inclusion of customary evidence in the national land law and subsequent communication of the revised law to the provincial, district, and village levels encourages the evolution of land dispute resolution institutions by expanding the menu of legitimate evidence.

Because all societies experience land conflict, what is important to a peace process is equitable access to legitimate land tenure dispute resolution institutions between groups who may view land resources very differently, possess profoundly different evidence with which to pursue claims, and may have participated or sympathized with different sides in the conflict. The Mozambican peace process is widely heralded as a success, in part by the way the land issue was handled. And, much attention is currently focused on the Mozambican case so that lessons learned can be tailored to the specifics of other peace process efforts.

\section{[A] References}

Bryant, R. 1992. Political Ecology: An Emerging Research Agenda in Third-World Studies. Political Geography 11:12-36.

Emel, J. and R. Peet. 1989. Resource Management and Natural Hazards. In R. Peet and N. Thrift, eds. New Models in Geography: The Political Economy Perspective, Volume 1, 49-76. London: Unwin Hyman.

Marston, S. 1983. Natural Hazards Research: Towards a Political Economy Perspective. Political Geography Quarterly 2:339-348.

Murphy, A. 1990. Historical Justifications for Territorial Claims. Annals of the Association of American Geographers 80:531-548.

Shipton, P. 1994. Land and Culture in Tropical Africa: Soils, Symbols, and the Metaphysics of the Mundane. Annual Review of Anthropology 23:347-377.

Sidaway, J. 1992. Mozambique: Destabilization, State, Society, and Space. Political Geography 11:239-258.

Unruh, J. 2001. Postwar Land Dispute Resolution: Land Tenure and the Peacekeeping Process in Mozambique. International Journal of World Peace 18:3-30.

Unruh J. 2002a. Local Land Tenure in the Peace Process. Peace Review 14:337-342.

Unruh J. 2002b. Land Dispute Resolution in Mozambique: Evidence and Institutions of Agroforestry Technology Adoption. In R, Meinzen-Dick, A. Mcculloch, F. Place, and 
B. Swallow, eds. Innovation in Natural Resource Management: The Role of Property Rights and Collective Action in Developing Countries, London: Johns Hopkins University Press.

Unruh, J. in press. Land Tenure and Legal Pluralism in the Peace Process. Peace and Change: A Journal of Peace Research. 